\title{
On the emissions and transport of bromoform: sensitivity to model resolution and emission location
}

\author{
M. R. Russo ${ }^{1,2}$, M. J. Ashfold ${ }^{1,3}$, N. R. P. Harris ${ }^{1}$, and J. A. Pyle ${ }^{1,2}$ \\ ${ }^{1}$ Department of Chemistry, University of Cambridge, Cambridge, UK \\ ${ }^{2}$ National Centre for Atmospheric Science (NCAS), Cambridge, UK \\ ${ }^{3}$ School of Biosciences, University of Nottingham Malaysia Campus, Jalan Broga, 43500 Semenyih, Selangor, Malaysia
}

Correspondence to: N. R. P. Harris (neil.harris@ozone-sec.ch.cam.ac.uk) and M. R. Russo (maria.russo@atm.ch.cam.ac.uk)

Received: 16 June 2015 - Published in Atmos. Chem. Phys. Discuss.: 31 July 2015

Revised: 3 December 2015 - Accepted: 4 December 2015 - Published: 21 December 2015

\begin{abstract}
Bromoform $\left(\mathrm{CHBr}_{3}\right)$ is a short-lived species with an important but poorly quantified ocean source. It can be transported to the Tropical Tropopause Layer (TTL), in part by rapid, deep convective lifting, from where it can influence the global stratospheric ozone budget. In a modelling study, we investigate the importance of the regional distribution of the emissions and of model resolution for the transport of bromoform to the TTL. We use two idealized $\mathrm{CHBr}_{3}$ emission fields (one coastal, one uniformly distributed across the oceans) implemented in high- and coarse-resolution (HR and $\mathrm{CR})$ versions of the same global model and focus on February as the period of peak convection in the West Pacific. Using outgoing long-wave radiation and precipitation as metrics, the HR version of the model is found to represent convection better. In the more realistic HR model version, the coastal emission scenario leads to $15-20 \%$ more $\mathrm{CHBr}_{3}$ in the global TTL, and up to three times more $\mathrm{CHBr}_{3}$ in the TTL over the Maritime Continent, than when uniform emissions of the same tropical magnitude are employed. Using the uniform emission scenario in both model versions, the distribution of $\mathrm{CHBr}_{3}$ at $15.7 \mathrm{~km}$ (approximately the level of zero net radiative heating) is qualitatively consistent with the differing geographic distributions of convection. However, averaged over the whole tropics, the amount of $\mathrm{CHBr}_{3}$ in the TTL in the two model versions is similar. Using the coastal scenario, in which emissions are particularly high in the Maritime Continent because of its long coastlines, the mixing ratio of $\mathrm{CHBr}_{3}$ in the TTL is enhanced over the Maritime Continent in both model versions. The enhancement is larger, and the peak in $\mathrm{CHBr}_{3}$ mixing ratio occurs at a higher altitude, in the HR model version. Our regional-scale results indicate
\end{abstract}

that using aircraft measurements and coarse global models to infer $\mathrm{CHBr}_{3}$ emissions will be very difficult, particularly if (as is possible) emissions are distributed heterogeneously and in regions of strong convective activity. In contrast, the global-scale agreement between our CR and HR calculations suggests model resolution is less vital for studies focused on the transport of bromine into the global stratosphere.

\section{Introduction}

Very short-lived halogenated substances (VSLS) are thought to make a significant but uncertain contribution to bromine in the stratosphere $(5 \pm 3$ ppt [i.e. $\sim 10-40 \%$ ] Br, Carpenter et al., 2014). Much of this uncertainty is linked to the contribution of bromoform $\left(\mathrm{CHBr}_{3}\right)$, which has both the shortest lifetime and the largest emissions of the commonly observed brominated VSLS.

The short lifetime of $\mathrm{CHBr}_{3}(\sim 15$ days in the tropical boundary layer; Carpenter et al., 2014) means that measurements in a particular location can only be used to constrain emissions over relatively small areas of the globe (e.g., Ashfold et al., 2014), and inventories are therefore uncertain (Quack and Wallace, 2003). To illustrate, recent estimates of total global emissions, constructed using various methodologies, range between 120-200 $\mathrm{Gg} \mathrm{Br} \mathrm{yr}^{-1}$ (Ziska et al., 2013) and $\sim 800 \mathrm{Gg} \mathrm{Br} \mathrm{yr}^{-1}$ (Yokouchi et al., 2005; Butler et al., 2007; O'Brien et al., 2009). Emissions from the oceans are believed to be the major source, but the relative importance of coastal and open-ocean emissions is unclear, with uncertainty here linked to the lack of information on the distribu- 
tion and relative strength of the dominant macro- and microalgal sources (Ordóñez et al., 2012; Stemmler et al., 2015).

Model estimates of the contribution that $\mathrm{CHBr}_{3}$ makes to $\mathrm{Br}$ in the stratosphere vary due to the assumed emission distribution (Hossaini et al., 2013), and also due to the treatment of chemical transformations of so-called product gases (e.g., Aschmann and Sinnhuber, 2013). A further source of uncertainty of $\mathrm{Br}$ injection into the stratosphere, again important because of the short $\mathrm{CHBr}_{3}$ lifetime, is its sensitivity to model representations of convective transport (e.g., Liang et al., 2014). This is likely to be particularly important when emissions and convective transport are spatially heterogeneous, and possibly co-located (e.g., Tegtmeier et al., 2012).

The peak outflow of convection occurs at altitudes around $12-13 \mathrm{~km}$ (corresponding to a potential temperature of $\sim 340 \mathrm{~K}$ and a pressure of $\sim 200 \mathrm{hPa}$ ), and the tropical tropopause layer (TTL) is the transition zone between these altitudes and the stratified stratosphere at $\sim 18 \mathrm{~km}(\sim 380 \mathrm{~K}$, $\sim 90 \mathrm{hPa}$ ) (Levine et al., 2007; Randel and Jensen, 2013). During Northern Hemisphere winter the strongest convection is found over the West Pacific and Maritime Continent, above the warm waters of the Tropical Warm Pool (Gettelman et al., 2002). This is thought to be the region of strongest transport of short-lived species from the ocean surface to the TTL (e.g. Levine et al., 2007).

Inherent to uncertainty around modelled convective transport is the spatial resolution of a model. The horizontal distribution of convection is less realistic in models with a coarse resolution (e.g., Russo et al., 2011; Chemel et al., 2015). In particular, coarse-resolution models fail to correctly represent geographical features around the Maritime Continent, where $\mathrm{CHBr}_{3}$ emissions might be large (Pyle et al., 2011), such as coastlines (Schiemann et al., 2014) and orography (Kirshbaum and Smith, 2009). As a consequence, they fail to resolve small-scale dynamical features such as sea breezes which often drive local circulation and convective development in coastal areas (Qian, 2008). In contrast, the vertical extent of convection and the associated vertical transport appears to depend more strongly on the convection parameterization rather than the model horizontal resolution (e.g. Hoyle et al., 2011).

Thus far, global model studies related to $\mathrm{CHBr}_{3}$ emissions and convective transport have generally employed coarse $\left(>2^{\circ}\right)$ horizontal grids, the resolution used in most climate model studies. Given the sensitivity of convection to resolution outlined above, can we trust these low-resolution models when they are used to construct "top-down" emission inventories (e.g. Warwick et al., 2006)? Are low-resolution models suitable for evaluation of the accuracy of those inventories against observations (e.g., Hossaini et al., 2013), or for simulating transport of $\mathrm{CHBr}_{3}$ towards the stratosphere in convectively active regions?

To begin to address these issues, in this study we employ a conventional, coarse-resolution version and a high-resolution version of the same global model to address two main ques- tions: (i) to what extent does transport of $\mathrm{CHBr}_{3}$ to the TTL depend on model resolution, and (ii) how does the efficiency of transport of $\mathrm{CHBr}_{3}$ in the two model versions differ when the tropical oceanic emissions are either spatially heterogeneous, being concentrated along shallow coastlines or are uniform across all oceans?

In Sect. 2 (Methodology), the model set-up is described. The idealized $\mathrm{CHBr}_{3}$ emission scenarios used are then discussed in Sect. 3, and the results regarding the quality of the model convection and its effect on $\mathrm{CHBr}_{3}$ transport are given in Sect. 4. Finally in Sect. 5, we summarize the main findings and discuss the implications, particularly for current estimates of global $\mathrm{CHBr}_{3}$ emissions.

\section{Methodology}

Model integrations are performed using the UK Chemistry and Aerosols (UKCA) model (Telford et al., 2010; Archibald et al., 2011; O'Connor et al., 2014), coupled to an atmosphere-only version of the UK Met Office Unified Model (UM version 7.3) (Hewitt et al., 2011).

A tropospheric chemistry scheme, described in Telford et al. (2010) and O'Connor et al. (2014), is used to represent chemical cycles of $\mathrm{O}_{x}, \mathrm{HO}_{x}$, and $\mathrm{NO}_{x}$ as well as the oxidation of $\mathrm{CO}$ and other non-methane hydrocarbons as previously described in Zeng and Pyle (2003). The oxidation of isoprene is included by implementation of the condensed Mainz Isoprene Mechanism (MIM) as described in Pöschl et al. (2000). Photolysis rates for photochemical reactions are calculated using the fast-JX photolysis scheme (Neu et al., 2007; Telford et al., 2013). For this study, a bromoform tracer has been added to the existing chemistry scheme. Its oxidation is determined by photolysis (Sander et al., 2006) and reaction with the model-calculated $\mathrm{OH}$ (DeMore et al., 1997). After oxidation, the bromine atoms are ignored, playing no further part in the model chemistry.

Present-day surface emissions for the chemical species are generated from the emission data set of Lamarque et al. (2010), as developed for the IPCC fifth assessment report. Isoprene emissions are taken from the POET database (Granier et al., 2005; Olivier et al., 2003). The general circulation for the periods under analysis is forced by prescribing monthly mean sea surface temperatures and sea ice cover from the AMIP data set (http://www-pcmdi.llnl.gov/ projects/amip).

The model is run in two different configurations. Firstly, coarse-resolution (CR) integrations are performed at a horizontal resolution of $3.75^{\circ}$ in longitude $\times 2.5^{\circ}$ in latitude (gridbox size $\sim 300 \mathrm{~km}$ ) with 60 sigma-height hybrid levels ( $\sim 80 \mathrm{~km}$ top). These levels follow earth's surface in the lower troposphere and transition to constant pressure surfaces in the stratosphere and above. Secondly, highresolution (HR) integrations are carried out at a horizontal resolution of $0.56^{\circ} \times 0.375^{\circ}$ (gridbox size $\sim 40 \mathrm{~km}$ ) with 63 


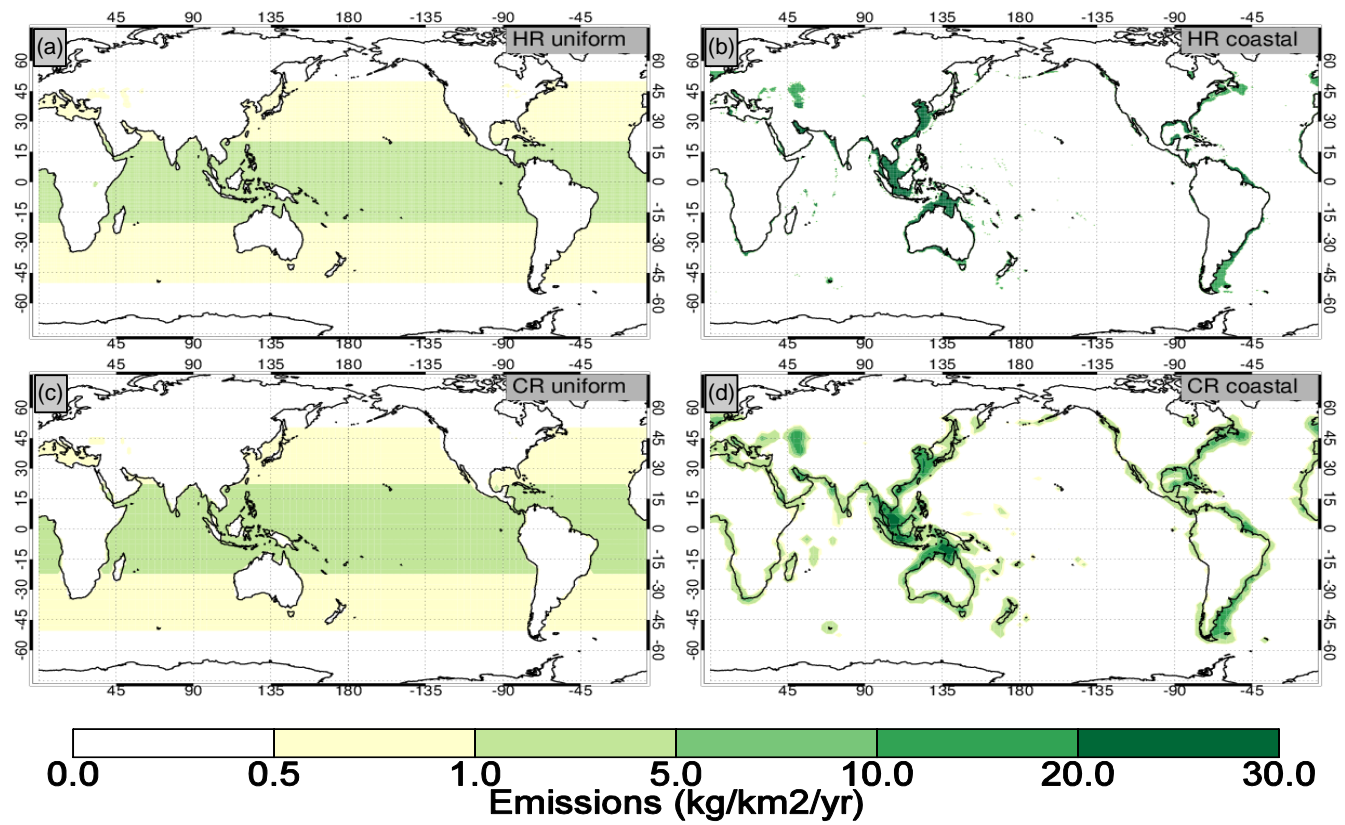

Figure 1. Tracer emission fields of $\mathrm{CHBr}_{3}$ used in the model runs described here: (a) uniform tracer and (b) coastal tracer in high-resolution run; (c) uniform tracer and (d) coastal tracer in coarse-resolution run.

sigma-height hybrid levels ( $\sim 40 \mathrm{~km}$ top). Horizontally, the area of an HR gridbox is $\sim 40$ times smaller than a CR gridbox, while vertically the average resolution in the troposphere is $600 \mathrm{~m}$ for CR compared to $360 \mathrm{~m}$ for HR. Note that the two model configurations are typically optimized for climate and weather forecast integrations respectively; therefore the impact of these further differences, which is difficult to disentangle from the simple effect of grid resolution, will also be reflected in our analysis.

One CR integration is performed spanning 10 years (1996-2005) following a 1-year spinup period while there are five separate HR timeslice integrations for the month of February and the years 1996, 1998, 2000, 2002, and 2005. A 4-month HR spin-up run is performed to initialize chemical fields (including bromoform tracers) prior to the February runs. A summary of the model integrations can be found in Table 1. Each integration is run with both a uniform ocean emission distribution and a coastal emission distribution, as discussed in the next section.

\section{Bromoform emissions}

In order to address the sensitivity of bromoform transport to model resolution, we designed two idealized bromoform emission data sets, both with a total of $400 \mathrm{Gg} \mathrm{yr}^{-1}$ of bromoform emitted. The two idealized emission data sets are prescribed as follows:

a. Uniform - emissions are uniformly distributed in model ocean gridboxes with $70 \%$ of the emissions in the trop- ics and the rest in the extra-tropics, in accordance with Scenario 3 in Warwick et al. (2006). For the purpose of this paper we define the tropics as the region between $20^{\circ} \mathrm{S}$ and $20^{\circ} \mathrm{N}$ and the extra-tropics as the region between 20 and $50^{\circ} \mathrm{N} / \mathrm{S}$.

b. Coastal - the Smith and Sandwell Global Seafloor Topography (Smith and Sandwell, 1997) was used to identify shallow sea areas (defined as having a depth less or equal to $200 \mathrm{~m}$ ) on the HR model grid. Emissions were distributed equally in all shallow-sea gridboxes between $50^{\circ} \mathrm{S}$ and $50^{\circ} \mathrm{N}$, which resulted in $50 \%$ of emissions in the tropics and $50 \%$ in the extra-tropics. These emissions were then interpolated onto the CR grid with an area-averaging technique, ensuring that the total amount emitted in similar domains (i.e. in the tropics and extratropics) is the same at both resolutions. Coastal emissions in the Maritime Continent are $29 \%$ of the total coastal emissions and $57 \%$ of the tropical coastal emissions.

The distribution of coastal and uniform emissions at both model resolutions is presented in Fig. 1. A third tracer was also used for comparative purposes:

c. Since the amount of bromoform emitted in the tropics is different in the coastal and uniform tracers, an additional uniform bromoform tracer was used in HR runs (Uniform_50), with only $50 \%$ of emissions distributed in the tropics. This allows us to compare directly the coastal and uniform_50 concentrations in the Tropics 
Table 1. Characteristics of models and simulations.

\begin{tabular}{lllllr}
\hline Name & Horizontal & Vertical & $\begin{array}{l}\text { Run } \\
\text { period }\end{array}$ & Tracers & $\begin{array}{r}\text { Tropical emissions } \\
\left(\mathrm{Gg} \mathrm{yr}^{-1}\right)\end{array}$ \\
\hline CR & $3.75^{\circ} \times 2.5^{\circ}$ & 60 levels & $1996-2005$ & Uniform & 280 \\
& & $(80 \mathrm{~km}$ top $)$ & & Coastal & 200 \\
\hline HR & $0.56^{\circ} \times 0.375^{\circ}$ & 63 levels & Feb 1996, 1998, & Uniform & 280 \\
& & $(40 \mathrm{~km}$ top $)$ & 2000,2002, & Coastal & 200 \\
& & 2005 & Uniform_50 & 200 \\
\hline
\end{tabular}
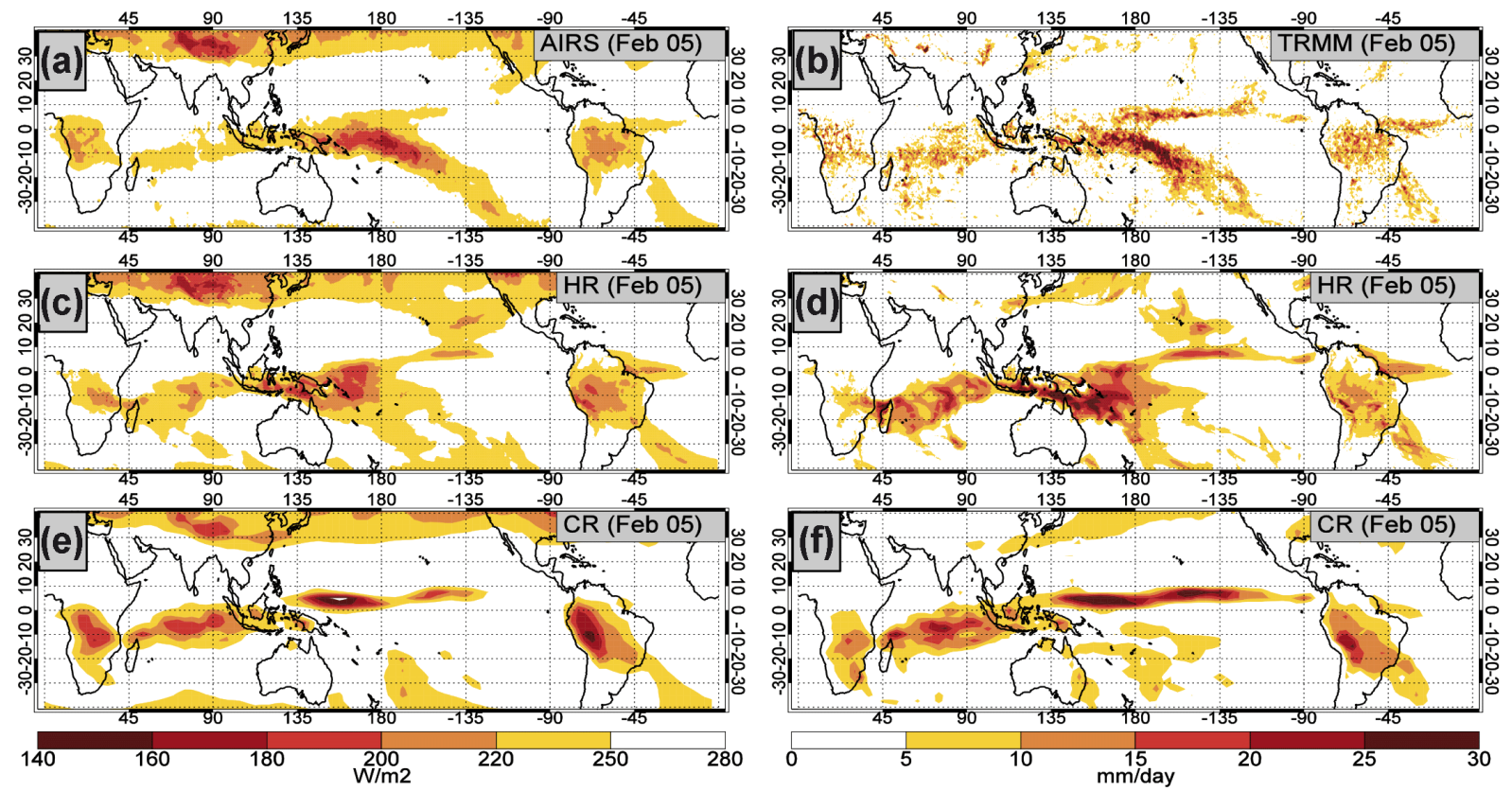

Figure 2. Observed and modelled fields for February 2005: (a) outgoing longwave radiation (OLR) from AIRS in W m ${ }^{-2}$; (b) precipitation from TRMM in mm day ${ }^{-1}$; (c) OLR and (d) precipitation for the high-resolution run; and (e) OLR and (f) precipitation for the coarseresolution run.

and therefore investigate the sensitivity of model convective transport on the spatial location of emissions.

\section{Results}

\subsection{Convection characteristics}

Monthly mean maps of Tropical Rainfall Measuring Mission (TRMM) observations of precipitation and from the Atmospheric Infrared Sounder (AIRS) observations of out-going long-wave radiation (OLR) are shown in Fig. 2 for February 2005 chosen as a representative February (see below) for which an HR run was available. Equivalent quantities for the coarse and high-resolution model runs are also shown. The most obvious differences compared to the observations are with the CR integration and are (a) the misplaced location of the convection in the CR run in the West Pacific with the maximum being incorrectly restricted to a narrow band as- sociated with the Inter-Tropical Convergence Zone (ITCZ); and (b) the overly strong continental convection in the CR model over S. America and S. Africa. This can be explained by differences in low-level circulation and surface moisture fluxes between CR and HR. With its larger grid box size, CR integrations fail to properly represent the sharp gradients between land and sea around the islands in the Maritime Continent and this leads to a poor representation of wind convergence and sea breezes. Over large continents, precipitation is often overestimated in CR, which leads to a positive feedback cycle of a more moist surface and further enhanced convection. Using either precipitation or OLR as a measure of model performance, it is evident that the high-resolution integrations perform better.

In the rest of this study, we concentrate on February 2005 to study differences in TTL bromoform concentrations arising from the different model resolutions or different distributions of emissions. OLR was anoma- 

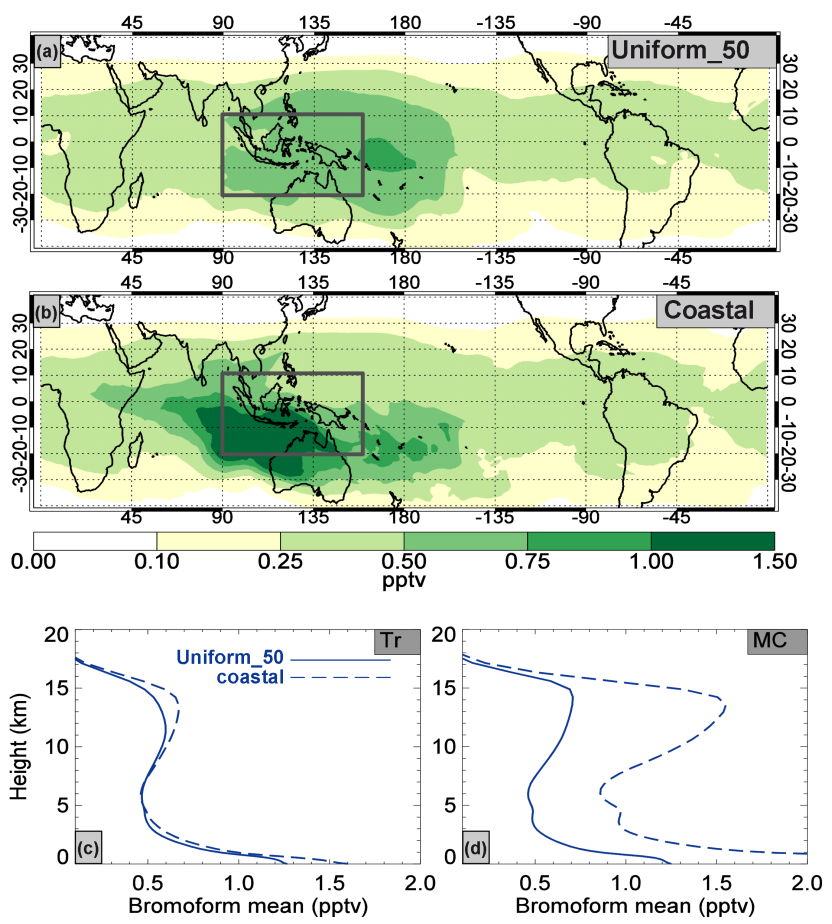

Figure 3. The monthly average mixing ratios at $15.7 \mathrm{~km}$ in February 2005 are shown for (a) the Uniform_50 tracer; and (b) the Coastal tracer. Average vertical profiles of the mixing ratios for the two tracers are shown for $(\mathbf{c})$ the Tropics $\left(20^{\circ} \mathrm{S}-20^{\circ} \mathrm{N}\right)$ and (d) the Maritime Continent $\left(20^{\circ} \mathrm{S}-10^{\circ} \mathrm{N} ; 90-160^{\circ} \mathrm{E}\right.$, as shown in (a) and (b)).

lously low over much of the Maritime Continent and northern Australia in February 2005, which was in the declining phase of a weak ENSO event (Oceanic Nino Index of 0.4 - http://www.cpc.ncep.noaa.gov/products/analysis_ monitoring/ensostuff/ensoyears.shtml). Nevertheless, a comparison of the 5-year average of the different high-resolution runs and the 10-year average from the coarse-resolution run shows broadly similar results (not shown), so the choice of year is not crucial. A comparison with the multi-year averages is given at the end of Sect. 4.2.2 to illustrate the relative magnitude of the variability calculated with the different model resolutions and emission scenarios.

\subsection{Bromoform transport}

In this section we first use the more realistic HR model to compare the cases with coastal emissions and uniform emissions. We then look at the effect of the model resolution.

\subsubsection{Coastal versus uniform emissions at high resolution}

Figure 3 shows the mixing ratio of $\mathrm{CHBr}_{3}$, comparing the Uniform_50 and Coastal tracers, at $15.7 \mathrm{~km}$ altitude in February 2005 calculated using the high-resolution model. An al- titude of $15.7 \mathrm{~km}$ is used as it is the model level close to, but above, the level of zero net radiative heating above which air will ascend into the stratosphere (see Russo et al. (2011) for a detailed discussion about the height of the zero radiative heating level). Figure 3 a shows the case where the emissions of $\mathrm{CHBr}_{3}$ are uniformly distributed across the tropical oceans, while Fig. $3 \mathrm{~b}$ shows the case for an equal amount of emissions concentrated in the shallow coastal regions. The mixing ratios in the TTL around the Maritime Continent are noticeably greater for the coastal emissions. This can be seen more clearly in panels $\mathrm{c}$ and $\mathrm{d}$ where the average vertical profiles are shown for the Tropics and for the Maritime Continent (indicated by the rectangle in the top two plots). The peak values for the Coastal tracer at $\sim 15 \mathrm{~km}$ are over twice as large as for the Uniform-50 tracer over the Maritime Continent. This is consistent with the enhanced emissions in this region due to the long coastlines (and hence large area with low ocean depth) associated with the islands (see Fig. 1) combined with the enhanced upward transport in convection over this region. Globally, the $\mathrm{CHBr}_{3}$ mixing ratio in the TTL is approximately 15-20\% higher when the coastal emissions are used. This is again due to a shorter time between emission and lofting into the TTL when the coastal emissions are collocated with the convection, leading to less chemical degradation of $\mathrm{CHBr}_{3}$ in the low and middle troposphere. These results, for February 2005, are robust across the 5 different years studies in the HR integrations.

The large local differences between $\mathrm{CHBr}_{3}$ calculated in the TTL for the different model emission distributions (but with the same magnitude of emissions across the tropics) has important implications for emissions derived from aircraft measurements. We discuss this further in Sect. 5.

\subsubsection{High resolution versus coarse resolution}

One aim of this study is to explore the effect of model resolution on the transport of $\mathrm{CHBr}_{3}$ into the TTL following emissions in tropics. Accordingly from now on, we use the Uniform $\mathrm{CHBr}_{3}$ tracers (Fig. 1a and c), rather than Uniform50 , at the two different model resolutions. Recall that, at either resolution, the Uniform tracer has $70 \%$ of its emissions in the tropics. By using separate tracers for tropical and extratropical emissions, the contribution of extratropical emissions to the total TTL mixing ratio is found to be small ( $\sim 10 \%$ for the Uniform tracer in the HR model). The effect of extra-tropical emissions (defined here as $20-50^{\circ} \mathrm{N} / \mathrm{S}$ ) on the $\mathrm{CHBr}_{3}$ TTL mixing ratios can, to first order, be discounted.

Figure $4 \mathrm{a}$ and $\mathrm{b}$ show the $15.7 \mathrm{~km} \mathrm{CHBr}_{3}$ field for February 2005 modelled with Uniform emissions from the highand coarse-resolution model runs, respectively. The overall mixing ratio patterns are consistent with the different distributions in convection over the oceanic source regions for $\mathrm{CHBr}_{3}$. There is a sharp peak in bromoform mixing ratios along the ITCZ in the CR calculation, associated with the 

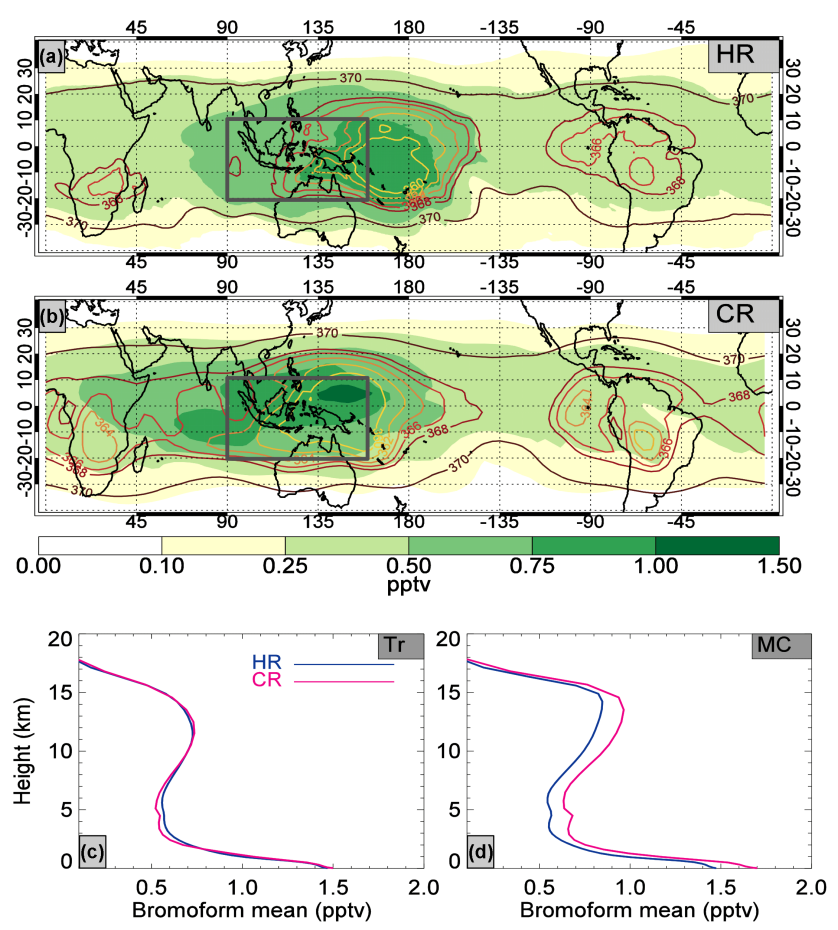

Figure 4. The monthly average mixing ratios for the Uniform tracer at $15.7 \mathrm{~km}$ in February 2005 are shown for (a) the high-resolution run; and (b) the coarse-resolution run. Contours of monthly average potential temperature are shown in (a) and (b). Average vertical profiles of the mixing ratios for the two runs are shown for (c) the Tropics $\left(20^{\circ} \mathrm{S}-20^{\circ} \mathrm{N}\right)$ and (d) the Maritime Continent $\left(20^{\circ} \mathrm{S}-10^{\circ} \mathrm{N} ; 90-160^{\circ} \mathrm{E}\right)$. High-resolution run is shown in blue; the coarse-resolution run is shown in pink.

unrealistic peak in convection discussed in Sect. 4.1. When averaged over the whole of the Tropics, the vertical profiles shown in panels $\mathrm{c}$ and $\mathrm{d}$ show little difference. However, we do find $\sim 10-15 \%$ higher mixing ratios at $15.7 \mathrm{~km}$ in the coarse-resolution run over the Maritime Continent.

Larger differences are seen between the coarse- and highresolution runs for the Coastal $\mathrm{CHBr}_{3}$ tracer (Fig. 5), with noticeably more $\mathrm{CHBr}_{3}$ lofted into the TTL in the highresolution run and with the peak value at a slightly higher altitude (Fig. 5d). This feature, with the peak at higher altitudes, is particularly prominent over the Maritime Continent. The maximum in the $\mathrm{CHBr}_{3}$ field on the $15.7 \mathrm{~km}$ surface does not coincide with the minimum in potential temperature in either the coarse- or high-resolution runs, as might be expected purely on the basis of the strength of convection. Rather the maximum tracer fields are seen to the south and west of the main convection.

These features are similar when considered in potential temperature coordinates, as can be seen from the potential temperature contours shown in Figs. 4a and 5a. The highest mixing ratios are found at levels between 365 and $370 \mathrm{~K}$ which are well above the main level of zero net radiative
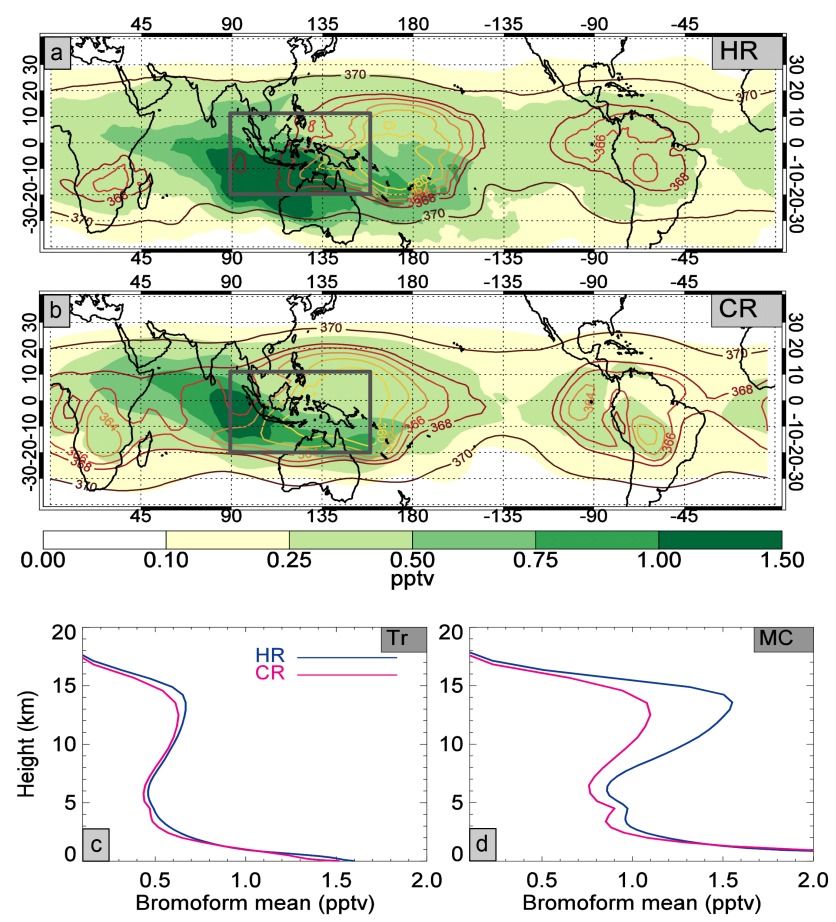

Figure 5. As for Fig. 4, except that these plots are for the Coastal Tracer.

heating; air at this level will be transported to the stratosphere either vertically or along isentropic surfaces into the extratropical lower stratosphere.

When the emission sources are heterogeneous, as is the case with the Coastal tracer emissions, the magnitude of the vertical transport for a short-lived gas will depend on the coincidence between source region and convective activity. In Sect. 4.1 we showed that the HR run captures the strong convection over the Maritime Continent better than at the coarser resolution (Fig. 2). This strong convection combined with the large coastal source around the Maritime Continent leads to the higher peak mixing ratios in bromoform, at higher altitudes (Fig. 5d), with enhanced transport likely into the stratosphere.

The representativeness of February 2005 can be examined by comparing the 5 years of the high-resolution run $(1996,1998,2000,2002,2005)$ with (a) the same 5 years (Fig. 6) and (b) all 10 years from the 10-year CR run (not shown). The same result was found for each comparison. Figure 6 shows the vertical profiles (mean and variability) of the $\mathrm{CHBr}_{3}$ tracer for four cases: the Uniform tracer averaged over (panel a) the whole Tropics and (panel b) the Maritime Continent; and (panels $\mathrm{c}$ and d) the Coastal tracer for the same two cases. With the Uniform tracer emissions, the tropical average profiles and associated variability for $\mathrm{CR}$ and $\mathrm{HR}$ shown in Fig. 6a are similar. The variability is greater over the Maritime Continent (Fig. 6b), as might be expected for a region whose convection is strongly influenced by ENSO 

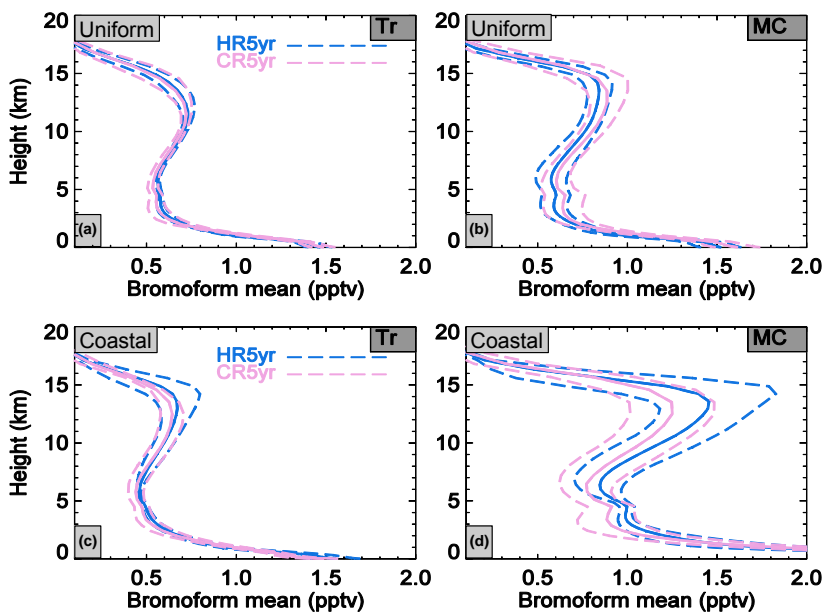

Figure 6. Average vertical profiles of the mixing ratios for the Uniform tracer in five representative Februaries (1996, 1998, 2000, $2002,2005)$ are shown for (a) the Tropics $\left(20^{\circ} \mathrm{S}-20^{\circ} \mathrm{N}\right)$ and (b) the Maritime Continent $\left(20^{\circ} \mathrm{S}-10^{\circ} \mathrm{N} ; 90-160^{\circ} \mathrm{E}\right)$. Equivalent plots for the Coastal tracer are shown in (c) and (d). High-resolution run is shown in blue; the coarse-resolution run is shown in pink. Dashed lines indicate 2 standard deviations from the mean (solid).

events, though the difference between CR and HR versions is still small. The variability found with the Coastal tracer is enhanced compared with the Uniform tracer in both HR and CR runs. This enhancement is most noticeable over the Maritime Continent where there is additionally a $10-15 \%$ increase in the peak $\mathrm{CHBr}_{3}$ tracer amount in the high-resolution run, indicating that the effect in February 2005 is typical, though larger than in other years.

It is also worth noting the small maximum in $\mathrm{CHBr}_{3}$ at $5 \mathrm{~km}$ over the Maritime Continent. This feature is present in the 5-year average as well as in 2005. We ascribe this to low-level convection around the coast-lines in the Maritime Continent as previously reported for Borneo (Robinson et al., 2012). It is not apparent in the latitude band average.

\section{Discussion and conclusions}

We use high- and coarse-resolution versions of the UKCA model to investigate the impact that model resolution and the geographical distribution of emissions have on $\mathrm{CHBr}_{3}$ mixing ratios in the TTL. The study focuses on February 2005, with its representativeness checked through comparisons with Februaries from other years. Comparing the OLR and the precipitation from the two model runs with observations shows that the HR model captures the convection more realistically than the CR run in terms of both strength and location. We ascribe this difference mainly to the HR model's better description of the low-level circulation and sea breezes associated with the larger islands of the Maritime Continent.
The HR model produces significant differences between how coastal and uniform emissions affect the $\mathrm{CHBr}_{3}$ mixing ratios in the TTL (Fig. 3). The effect varies regionally with, for example, over twice as much $\mathrm{CHBr}_{3}$ over the Maritime Continent for the coastal emission case. When averaged over the global TTL there is $15-20 \%$ more $\mathrm{CHBr}_{3}$ in the TTL with the Coastal emissions. Several of the $\mathrm{CHBr}_{3}$ emission estimates currently used in global models are based, at least in part, on aircraft measurements made in the free troposphere and TTL (e.g., Warwick et al., 2006; Liang et al., 2010; Ordóñez et al., 2012). The inhomogeneity in Fig. 3b shows that estimates based on aircraft measurements are sensitive to (a) the location of the measurements; (b) the description of convection in the model used; and (c) the assumed ratio of coastal and open-ocean emissions. Many of the aircraft measurements used to derive global emissions are located in or around the Pacific Ocean (e.g., Liang et al., 2010; Navarro et al., 2015), where our calculations indicate higher than average TTL mixing ratios for $\mathrm{CHBr}_{3}$. It seems likely that global emission estimates based on these aircraft measurements could be biased high, which could offer an explanation for some of the current discrepancies between the various estimates (Carpenter et al., 2014). The larger the relative contribution of coastal emissions, the more important this factor will be. Conversely, aircraft measurements can likely be used to improve regional (and hence global) emission estimates. Such a region-by-region approach would probably require more measurements than is currently available.

The transport of short-lived species into the TTL and on to the stratosphere depends on the location of the emissions and on the location of the major vertical ascent occurring in convection. A maximum flux into the TTL would occur when the region of emission and convection exactly coincide. On the other hand, if emission is far from convection then it is likely that substantial chemical loss could occur before any rapid vertical transport; the overall flux into the TTL would then be low. Convection is modelled better at higher resolution so the difference between $\mathrm{TTL} \mathrm{CHBr}_{3}$ calculated for the Uniform or Coastal tracers can be large in some regions, as discussed above. For our CR integrations, the difference in the global TTL mixing ratios of $\mathrm{CHBr}_{3}$ due to emission distribution is smaller (compare Fig. 4c, d with Fig. 5c, d). Other models run at coarse resolution might also be expected to underestimate the amount of short-lived tracer lifted to TTL regionally, with the underestimation differing from year-toyear (Fig. 6).

The differences are largest for short-lived species, and so the major effect on the stratospheric Bry budget will be felt through $\mathrm{CHBr}_{3}$ with its tropical lifetime of $\sim 15$ days and a potentially large proportion of emissions in coastal regions. Similarly, if iodine-containing species play a role in upper tropospheric and stratospheric chemistry (Saiz-Lopez et al., 2015), understanding their precise emission locations will be important and high-resolution modelling will be required to capture their local impact. On the other hand, the calculated 
TTL mixing ratio of the other major short-lived contributor to stratospheric bromine, dibromomethane $\left(\mathrm{CH}_{2} \mathrm{Br}_{2}\right)$, will be relatively unaffected by the model resolution as it has a $\sim 3$ month tropical lifetime (Carpenter et al., 2014) and dominant open-ocean sources (Ziska et al., 2013).

We have not examined differences in the impact on the stratosphere for the different model resolutions and emission distributions. This would require a complete model calculation, where the degradation products of bromoform are modelled in a fully interactive chemistry scheme. We note that the multi-year averages of the $\mathrm{CHBr}_{3}$ mixing ratios in the global TTL are similar for the CR and HR models implying that the large-scale performance of the two models is reasonably similar when the total emissions are the same. This suggests that the resolution of the models currently used in multiannual integrations to study the transport of bromine into the global stratosphere is acceptable (although unacceptable if the aim is to compare model results with observed chemical distributions in the TTL or to infer emissions). However, because the details of the convection do change with resolution, any changes in the preferred transport pathways with climate change may not be accurately modelled.

Acknowledgements. This work was supported through the ERC ACCI project (project no. 267760), and by NERC through grant nos. NE/J006246/1 and NE/F1016012/1. N. R. P. Harris was supported by a NERC Advanced Research Fellowship (NE/G014655/1).

Edited by: R. Müller

\section{References}

Archibald, A., Levine, J., Abraham, N., Cooke, M., Edwards, P., Heard, D., Jenkin, M., Karunaharan, A., Pike, R., Monks, P., Shallcross, D., Telford, P., Whalley, L., and Pyle, J.: Impacts of $\mathrm{HO}_{x}$ regeneration and recycling in the oxidation of isoprene: Consequences for the composition of past, present and future atmospheres, Geophys. Res. Lett., 38, L05804, doi:10.1029/2010GL046520, 2011.

Aschmann, J. and Sinnhuber, B.-M.: Contribution of very shortlived substances to stratospheric bromine loading: uncertainties and constraints, Atmos. Chem. Phys., 13, 1203-1219, doi:10.5194/acp-13-1203-2013, 2013.

Ashfold, M. J., Harris, N. R. P., Manning, A. J., Robinson, A. D., Warwick, N. J., and Pyle, J. A.: Estimates of tropical bromoform emissions using an inversion method, Atmos. Chem. Phys., 14, 979-994, doi:10.5194/acp-14-979-2014, 2014.

Butler, J. H., King, D. B., Lobert, J. M., Montzka, S. A., YvonLewis, S. A., Hall, B. D., Warwick, N. J., Mondeel, D. J., Aydin, M., and Elkins, J. W.: Oceanic distributions and emissions of short-lived halocarbons, Global Biogeochem. Cy., 21, GB1023, doi:10.1029/2006GB002732, 2007.

Carpenter, L. J., Reimann, S., Burkholder, J. B., Clerbaux, C., Hall, B. D., Hossaini, R., Laube, J. C., and Yvon-Lewis, S. A.: OzoneDepleting Substances (ODSs) and Other Gases of Interest to the
Montreal Protocol, Chapter 1 in Scientific Assessment of Ozone Depletion: 2014, Update on Global Ozone Research and Monitoring Project - Report No. 55, World Meteorological Organization, Geneva, Switzerland, 2014.

Chemel, C., Russo, M. R., Hosking, J. S., Telford, P. J., and Pyle, J. A.: Sensitivity of tropical deep convection in global models: effects of horizontal resolution, surface constraints, and 3D atmospheric nudging, Atmos. Sci. Lett., 16, 148-154, doi:10.1002/asl2.540, 2015.

DeMore, W. B., Sander, S. P., Golden, D. M., Hampson, R. F., Kurylo, M. J., Howard, C. J., Ravishankara, A. R., Kolb, C. E., and Molina, M. J.: Chemical Kinetics and Photochemical Data for Use in Stratospheric Modeling, JPL Publication 97-4, Jet Propulsion Laboratory, Pasadena, 1997.

Gettelman, A., Salby, M. L., and Sassi, F.: Distribution and influence of convection in the tropical tropopause region, J. Geophys. Res., 107, ACL6.1-ACL6.12, doi:10.1029/2001JD001048, 2002.

Granier, C., Guenther, A., Lamarque, J., Mieville, A., Muller, J., Olivier, J., Orlando, J., Peters, J., Petron, G., Tyndall, G., and Wallens, S.: POET, a database of surface emissions of ozone precursors, available at: http://www.pole-ether.fr/eccad (last access: May 2013), ECCAD-Ether Database, 2005.

Hewitt, H. T., Copsey, D., Culverwell, I. D., Harris, C. M., Hill, R. S. R., Keen, A. B., McLaren, A. J., and Hunke, E. C.: Design and implementation of the infrastructure of HadGEM3: the nextgeneration Met Office climate modelling system, Geosci. Model Dev., 4, 223-253, doi:10.5194/gmd-4-223-2011, 2011.

Hossaini, R., Mantle, H., Chipperfield, M. P., Montzka, S. A., Hamer, P., Ziska, F., Quack, B., Krüger, K., Tegtmeier, S., Atlas, E., Sala, S., Engel, A., Bönisch, H., Keber, T., Oram, D., Mills, G., Ordóñez, C., Saiz-Lopez, A., Warwick, N., Liang, Q., Feng, W., Moore, F., Miller, B. R., Marécal, V., Richards, N. A. D., Dorf, M., and Pfeilsticker, K.: Evaluating global emission inventories of biogenic bromocarbons, Atmos. Chem. Phys., 13, 11819-11838, doi:10.5194/acp-13-11819-2013, 2013.

Hoyle, C. R., Marécal, V., Russo, M. R., Allen, G., Arteta, J., Chemel, C., Chipperfield, M. P., D’ Amato, F., Dessens, O., Feng, W., Hamilton, J. F., Harris, N. R. P., Hosking, J. S., Lewis, A. C., Morgenstern, O., Peter, T., Pyle, J. A., Reddmann, T., Richards, N. A. D., Telford, P. J., Tian, W., Viciani, S., Volz-Thomas, A., Wild, O., Yang, X., and Zeng, G.: Representation of tropical deep convection in atmospheric models - Part 2: Tracer transport, Atmos. Chem. Phys., 11, 8103-8131, doi:10.5194/acp-118103-2011, 2011.

Kirshbaum, D. J. and Smith, R. B.: Orographic precipitation in the tropics: large-eddy simulations and theory, J. Atmos. Sci., 66, 2559-2578, doi:10.1175/2009JAS2990.1, 2009.

Lamarque, J.-F., Bond, T. C., Eyring, V., Granier, C., Heil, A., Klimont, Z., Lee, D., Liousse, C., Mieville, A., Owen, B., Schultz, M. G., Shindell, D., Smith, S. J., Stehfest, E., Van Aardenne, J., Cooper, O. R., Kainuma, M., Mahowald, N., McConnell, J. R., Naik, V., Riahi, K., and van Vuuren, D. P.: Historical (1850-2000) gridded anthropogenic and biomass burning emissions of reactive gases and aerosols: methodology and application, Atmos. Chem. Phys., 10, 7017-7039, doi:10.5194/acp10-7017-2010, 2010.

Levine, J. G., Braesicke, P., Harris, N. R. P., Savage, N. H., and Pyle, J. A.: Pathways and timescales for troposphere-to-stratosphere 
transport via the tropical tropopause layer and their relevance for very short lived substances, J. Geophys. Res., 112, D04308, doi:10.1029/2005JD006940, 2007.

Liang, Q., Stolarski, R. S., Kawa, S. R., Nielsen, J. E., Douglass, A. R., Rodriguez, J. M., Blake, D. R., Atlas, E. L., and Ott, L. E.: Finding the missing stratospheric Bry: a global modeling study of $\mathrm{CHBr}_{3}$ and $\mathrm{CH}_{2} \mathrm{Br}_{2}$, Atmos. Chem. Phys., 10, 2269-2286, doi:10.5194/acp-10-2269-2010, 2010.

Liang, Q., Atlas, E., Blake, D., Dorf, M., Pfeilsticker, K., and Schauffler, S.: Convective transport of very short lived bromocarbons to the stratosphere, Atmos. Chem. Phys., 14, 5781-5792, doi:10.5194/acp-14-5781-2014, 2014.

Navarro, M. A., Atlas, E., Saiz-Lopez, A., Rodriguez-Llovera, X., Kinnison, D. E., Lamarque, J.-F., Tilmes, S., Filus, M., Harris, N. R. P., Meneguz, E., Ashfold, M. J., Manning, A. J., Cuevas, C. A. Schauffler, S. M., and Donets, V.: Airborne measurements of organic bromine compounds in the Pacific tropical tropopause layer, P. Natl. Acad. Sci., 112, 13789-13793, doi:10.1073/pnas.1511463112, 2015.

Neu, J. L., Prather, M. J., and Penner, J. E.: Global atmospheric chemistry: Integrating over fractional cloud cover, J. Geophys. Res., 112, D11306, doi:10.1029/2006JD008007, 2007.

O'Brien, L. M., Harris, N. R. P., Robinson, A. D., Gostlow, B., Warwick, N., Yang, X., and Pyle, J. A.: Bromocarbons in the tropical marine boundary layer at the Cape Verde Observatory - measurements and modelling, Atmos. Chem. Phys., 9, 9083-9099, doi:10.5194/acp-9-9083-2009, 2009.

O'Connor, F. M., Johnson, C. E., Morgenstern, O., Abraham, N. L., Braesicke, P., Dalvi, M., Folberth, G. A., Sanderson, M. G., Telford, P. J., Voulgarakis, A., Young, P. J., Zeng, G., Collins, W. J., and Pyle, J. A.: Evaluation of the new UKCA climatecomposition model - Part 2: The Troposphere, Geosci. Model Dev., 7, 41-91, doi:10.5194/gmd-7-41-2014, 2014.

Olivier, J., Peters, J., Granier, C., Petron, G., Muller, J., and Wallens, S.: Present and future surface emissions of atmospheric compounds, pOET Report 2, EU project EVK2-1999-00011, 2003.

Ordóñez, C., Lamarque, J.-F., Tilmes, S., Kinnison, D. E., Atlas, E. L., Blake, D. R., Sousa Santos, G., Brasseur, G., and Saiz-Lopez, A.: Bromine and iodine chemistry in a global chemistry-climate model: description and evaluation of very short-lived oceanic sources, Atmos. Chem. Phys., 12, 1423-1447, doi:10.5194/acp12-1423-2012, 2012.

Pöschl, U., von Kuhlmann, R., Poisson, N., and Crutzen, P.: Development and intercomparison of condensed isoprene oxidation mechanisms for global atmospheric modeling, J. Atmos. Chem., 37, 29-52, 2000.

Pyle, J. A., Ashfold, M. J., Harris, N. R. P., Robinson, A. D., Warwick, N. J., Carver, G. D., Gostlow, B., O’Brien, L. M., Manning, A. J., Phang, S. M., Yong, S. E., Leong, K. P., Ung, E. H., and Ong, S.: Bromoform in the tropical boundary layer of the Maritime Continent during OP3, Atmos. Chem. Phys., 11, 529-542, doi:10.5194/acp-11-529-2011, 2011.

Qian, J.-H.: Why Precipitation Is Mostly Concentrated over Islands in the Maritime Continent, J. Atmos. Sci., 65, 1428-1441, doi:10.1175/2007JAS2422.1, 2008.

Quack, B. and Wallace, D. W. R.: Air-sea flux of bromoform: Controls, rates, and implications, Global Biogeochem. Cy., 17, 1023, doi:10.1029/2002GB001890, 2003.
Randel, W. and Jensen, E.: Physical processes in the tropical tropopause layer and their roles in a changing climate, Nat. Geosci., 6, 169-176, doi:10.1038/ngeo1733, 2013.

Robinson, N. H., Allan, J. D., Trembath, J. A., Rosenberg, P. D., Allen, G., and Coe, H.: The lofting of Western Pacific regional aerosol by island thermodynamics as observed around Borneo, Atmos. Chem. Phys., 12, 5963-5983, doi:10.5194/acp-12-59632012, 2012.

Russo, M. R., Marécal, V., Hoyle, C. R., Arteta, J., Chemel, C., Chipperfield, M. P., Dessens, O., Feng, W., Hosking, J. S., Telford, P. J., Wild, O., Yang, X., and Pyle, J. A.: Representation of tropical deep convection in atmospheric models - Part 1: Meteorology and comparison with satellite observations, Atmos. Chem. Phys., 11, 2765-2786, doi:10.5194/acp-11-27652011, 2011.

Saiz-Lopez, A., Baidar, S., Cuevas, C. A., Koenig, T. K., Fernandez, R. P., Dix, B., Kinnison, D. E., Lamarque, J.-F., RodriguezLloveras, X., Campos, T. L., and Volkamer, R.: Injection of iodine to the stratosphere, Geophys. Res. Lett., 42, 6852-6859, 2015.

Sander, S. P., Finlayson-Pitts, B. J., Friedl, R. R., Golden, D. M. , Huie, R. E., Keller-Rudek, H., Kolb, C. E., Kurylo, M. J., Molina, M. J., Moortgat, G. K., Orkin, V. L., Ravishankara A. R., and Wine, P. H.: Chemical Kinetics and Photochemical Data for Use in Atmospheric Studies, Evaluation Number 15, JPL Publication 06-2, Jet Propulsion Laboratory, Pasadena, 2006.

Schiemann, R., Demory, M.-E., Mizielinski, M., Roberts, M., Shaffrey, L., Strachan, J., and Vidale, P.: The sensitivity of the tropical circulation and Maritime Continent precipitation to climate model resolution, Clim. Dynam., 42, 2455-2468, doi:10.1007/s00382-013-1997-0, 2014.

Smith, W. H. F. and Sandwell, D. T.: Global seafloor topography from satellite altimetry and ship depth soundings, Science, 277 , 1957-1962, 1997.

Stemmler, I., Hense, I., and Quack, B.: Marine sources of bromoform in the global open ocean - global patterns and emissions, Biogeosciences, 12, 1967-1981, doi:10.5194/bg-12-1967-2015, 2015 .

Tegtmeier, S., Krüger, K., Quack, B., Atlas, E. L., Pisso, I., Stohl, A., and Yang, X.: Emission and transport of bromocarbons: from the West Pacific ocean into the stratosphere, Atmos. Chem. Phys., 12, 10633-10648, doi:10.5194/acp-12-10633-2012, 2012.

Telford, P. J., Lathière, J., Abraham, N. L., Archibald, A. T., Braesicke, P., Johnson, C. E., Morgenstern, O., O’Connor, F. M., Pike, R. C., Wild, O., Young, P. J., Beerling, D. J., Hewitt, C. N., and Pyle, J.: Effects of climate-induced changes in isoprene emissions after the eruption of Mount Pinatubo, Atmos. Chem. Phys., 10, 7117-7125, doi:10.5194/acp-10-7117-2010, 2010.

Telford, P. J., Abraham, N. L., Archibald, A. T., Braesicke, P., Dalvi, M., Morgenstern, O., O’Connor, F. M., Richards, N. A. D., and Pyle, J. A.: Implementation of the Fast-JX Photolysis scheme (v6.4) into the UKCA component of the MetUM chemistry-climate model (v7.3), Geosci. Model Dev., 6, 161177, doi:10.5194/gmd-6-161-2013, 2013. 
Warwick, N. J., Pyle, J. A., Carver, G. D., Yang, X., Savage, N. H., O'Connor, F. M., and Cox, R. A.: Global modeling of biogenic bromocarbons, J. Geophys. Res., 111, D24305, doi:10.1029/2006JD007264, 2006.

Yokouchi, Y., Hasebe, F., Fujiwara, M., Takashima, H., Shiotani, M., Nishi, N., Kanaya, Y., Hashimoto, S., Fraser, P., ToomSauntry, D., Mukai, H., and Nojiri, Y.: Correlations and emission ratios among bromoform, dibromochloromethane, and dibromomethane in the atmosphere, J. Geophys. Res., 110, D23309, doi:10.1029/2005JD006303, 2005.

Zeng, G. and Pyle, J.: Changes in tropospheric ozone between 2000 and 2100 modeled in a chemistry-climate model, Geophys. Res. Lett., 30, 1392, doi:10.1029/2002GL016708, 2003.
Ziska, F., Quack, B., Abrahamsson, K., Archer, S. D., Atlas, E., Bell, T., Butler, J. H., Carpenter, L. J., Jones, C. E., Harris, N. R. P., Hepach, H., Heumann, K. G., Hughes, C., Kuss, J., Krüger, K., Liss, P., Moore, R. M., Orlikowska, A., Raimund, S., Reeves, C. E., Reifenhäuser, W., Robinson, A. D., Schall, C., Tanhua, T., Tegtmeier, S., Turner, S., Wang, L., Wallace, D., Williams, J., Yamamoto, H., Yvon-Lewis, S., and Yokouchi, Y.: Global sea-toair flux climatology for bromoform, dibromomethane and methyl iodide, Atmos. Chem. Phys., 13, 8915-8934, doi:10.5194/acp13-8915-2013, 2013. 